\title{
Food Security and its Determinants among Urban Households: A Case Study of Maiduguri and Jere Local Government Areas of Borno State, Nigeria.
}

\author{
F. F. Ahmed \\ Department of Economics, University of Maiduguri \\ P. S. Amaza \\ Department of Agricultural Economics, University of Jos \\ P. V. Kwaghe \\ Department of Agricultural Economics, University of Maiduguri
}

\begin{abstract}
The paper examined food security and its determinants among urban households in selected Local Government Areas in Borno State, Nigeria. Data were collected from 360 randomly selected households through the use of well structured questionnaires. Descriptive statistics, Cost of Calorie Function (COC) and Logit regression model were employed to analyze the data. Mean age of respondents was 47 years and an average of nine years was spent in formal education. Mean household size, farm size and monthly income was six persons, 0.7 hectares and about $\mathrm{N69}, 000.00$ respectively. Major sources of income were from civil service, petty trading, agro-processing and trading. About $60 \%$ of the sample households were food secure, 10 out of 14 variables included in the model were significant determinants food security status among urban households. These variables are family size, education, extension agent's contact, credit, assets, income and diet diversity, farm size, child dependency ratio and family labour. Results proved that households' engagement in combination of enterprises and off-farm activities could boost income generation drive Also, increased awareness and more access to family planning facilities were proffered.
\end{abstract}

Keywords: Food Security, Determinants, income generation, calorie intake, urban households

\section{INTRODUCTION}

Food is said to be a basic means of sustenance and its quality intake is also a key requirement for healthy and productive life. FAO (2001) observed that food security "exists when all people, at all times, have physical, economic, and social access to sufficient, safe and nutritious food to meet their dietary needs and food preferences for an active and healthy life". Within the framework of this definition, food security requires fulfilling certain conditions related to the supply, demand and household-level utilization of food. Everyone should at all times, have food in adequate quantity and quality. The quantity of food available must not only be adequate on the aggregate but there must also be per-capita adequacy at all times. Access in this respect must not be only by own production (subsistence) but also from the market with consumers having adequate purchasing power to constitute effective demand. Food security for a household means access by all members at all times to enough food for an active, healthy life. Food security includes at a minimum the ready availability of nutritionally adequate and safe foods, an assured ability to acquire acceptable foods in socially acceptable ways (that is, without resorting to emergency food supplies, scavenging, stealing, or other coping strategies). 
Household food security situation in Nigeria therefore shows the extent which the household has access to adequate nutritional food (Eze, 2003).

Evidence in Nigeria shows that there is enough aggregate food production/supply but the observed food insecurity is as a result of poor storage, marketing and unequal economic access to available food supplies rooted in unequal distribution of income and wealth (Orewa et al. 2009). Achieving food security is a major challenge among urban households in the light of minimal crop production practices and food items are purchased in the market at prevailing prices subject to available resources. Household food security depends substantially on household income and asset (or wealth) status. A low-income household is more likely to suffer food shortages than a wealthier household. Food expenditure comprises a large share of the spending of poor households, making them relatively more vulnerable to the impacts of food price inflation. This relationship between a household's food security status and its purchasing power is far from static; it changes over time (Ahmed, 2014; Aliber, 2009 and Kaloi et al., 2005). All other factors remaining constant, changes in income alter the quantity and quality of foods purchased and consumed. Price movements of food and non-food items also affect the ability to buy food.

Another problem according to the Ministry of Agriculture and Water Resources, responsible for the food crisis in Nigeria is not unconnected with the fact that "Nigeria's agriculture is mainly rain-fed and she has not taken full advantage of its irrigation potential estimated between two and 2.5 million hectares". The area under irrigation is officially estimated at about 220,000 hectares or less than one per cent of the total areas under crops. The contribution of irrigated agriculture to crop production is, therefore, very small (Ojo et al. 2012 and Davies, 2009).

Furthermore, in Nigeria, drought and political situation in neighboring countries like Chad, Cameroun and Niger seem to pose a threat to a State like Borno as they rely on the State for their food supplies. The State is besieged by an alarming rate of insecurity which invariably affects socio-economic activities. Agricultural production is severely affected resulting in low food production, high food prices, low food consumption and ultimately food insecurity in the urban settlements which solely depend on agricultural outputs sold in the market. Also, households continue to face varied economic conditions which impact on their living standard and food security situation which consequently create gaps in resource availability and considerable imbalance between the demand and supply of food among the households. The impact of this is that the food situation gets worse, hence food insecurity.

This study, therefore empirically measured food security status of households in Maiduguri and Jere Local Government Areas (LGAs) which are the major urban areas and commercial nerve centers of Borno State. The specific objectives of the study examined the socio-economic characteristics of the respondents; estimated the calorie intake of the urban households; measured their food security status; and examined the determinants of food security status among the urban households in Borno State, Nigeria.

The study was conducted in Borno State located in the North-eastern part of Nigeria. It lies between latitudes $120.00 \mathrm{~N}$ and $140.00 \mathrm{~N}$ and longitudes $100.00 \mathrm{E}$ and 140.00 E. Within the north-east, the State shares borders with Adamawa State to the south, Yobe State to the west, and Gombe State to the southwest. It also shares International borders with the Republic of Niger to the north, Chad to the north-east and Cameroon to the East. The state has an area of 
$75,540 \mathrm{~km} 2$ and 27 Local Government Areas spread over four major agro-ecological zones. Agriculture is the main stay of the State's economy. The major crops cultivated in the State are millet, sorghum, maize, groundnut, wheat, cowpea, soybeans (which has become a major crop in southern Borno in recent years) and vegetables (onions, pepper, tomatoes, garden eggs and other leafy vegetables). The major livestock reared in the State are cattle, camel, sheep and goats (Kwaghe, 2006). Majority of the populace of the Maiduguri and Jere Metropolis are civil servants, traders, military and paramilitary and artisans. These households depend mainly on food items from the rural areas of the State and from neighboring States in Nigeria.

\section{Sampling Technique}

\section{METHODOLOGY}

Multistage sampling technique was employed for this study. The first stage involved the purposive selection of Maiduguri and Jere Local Government Areas (LGAs). The selected LGAs are the commercial nerve centers of the State and also represent the major urban settlements. Purposive sampling was also employed in the second stage in selecting the three wards based on population density in each of the LGAs. These wards were also selected to represent the three income groups (low, medium and high respectively). The wards selected in Maiduguri LGA were Wulari, Gwange and Federal low-Cost housing estate while the wards selected in Jere LGA were Mairi, New Government Residential Area (GRA) and University of Maiduguri quarters which also represent the three income groups in the same order. The third stage involved the random selection of households from the wards. Residential locations were used as proxy to capture different income groups in these urban settlements. However, this does not mean that a particular ward consist only a particular income group residing there. It is possible that all the three (3) income groups be found in a particular ward, but this is done to ensure that the three income groups were adequately captured in the urban settlements. Seventy (70) urban households were randomly selected from each of the six wards making a total of 420 households. However, only data from 360 respondents in the urban LGAs were analyzed as others were discarded for inconsistency or incompleteness.

\section{Analytical Technique}

Descriptive statistics was used to examine the socio-economic characteristics of respondents. Inferential statistics the cost-of-calories (COC), proposed by Greer and Thorbecke (1986) was used to estimate the food security line. The method yields a value that is usually close to the minimum calorie requirements for human survival. A minimum level of nutrition necessary to maintain healthy living was identified. This minimum level is referred to as the 'food security line' for the area under study, below which people are classified as food insecure, subsisting on inadequate nutrition. Calorie adequacy was estimated by dividing the estimated calorie supply for the households by the household size adjusted for adult equivalence using the consumption factor for age-sex categories (Table 1). The food security line is given as:

$\ln \mathrm{X}=\mathrm{a}+\mathrm{bC}-$

Where:

$\mathrm{X}=$ adult equivalent food expenditure (in Naira) and

$\mathrm{C}=$ actual calorie consumption per adult equivalent of a household (in kilocal).

The calorie content of the recommended minimum daily nutrients level (L) 2260Kcal employed by (Babatunde et al. (2007): FAO, 2009; Oluyole 2009) was used to determine the food security line $S$ using the equation:

$\mathrm{S}=\mathrm{e}(\mathrm{a}+\mathrm{bL})-$

Where: $\mathrm{S}=$ cost of buying the minimum calorie intake (food security line); 
$\mathrm{a}=$ Intercept;

$\mathrm{b}=$ Coefficient of the calorie consumption;

$\mathrm{L}=\mathrm{FAO}$ recommended minimum daily energy (calorie) level.

Table 1: Conversion factors for calorie requirement for different age groups

\begin{tabular}{lll}
\hline Age category & Male & Female \\
\hline $0-1$ & 0.33 & 0.33 \\
$1-2$ & 0.46 & 0.46 \\
$2-3$ & 0.54 & 0.54 \\
$3-5$ & 0.62 & 0.62 \\
$5-7$ & 0.74 & 0.70 \\
$7-10$ & 0.84 & 0.72 \\
$10-12$ & 0.88 & 0.78 \\
$12-14$ & 0.96 & 0.84 \\
$14-16$ & 1.06 & 0.86 \\
$16-18$ & 1.14 & 0.86 \\
$18-30$ & 1.04 & 0.80 \\
$30-60$ & 1.00 & 0.82 \\
$>60$ & 0.84 & 0.74 \\
\hline
\end{tabular}

Source: Babatunde et al. 2007

\section{Logit Model}

In the Logit model, the data on the dependent variable (food security status) is bivariate, that is, food secure and food insecure households. The model assumes that being food secure is a continuous status. The model expresses households' food security status as a function of linear combination of observable explanatory variables, some unknown parameters and an error term (e)

The implicit form of the model is expressed as:

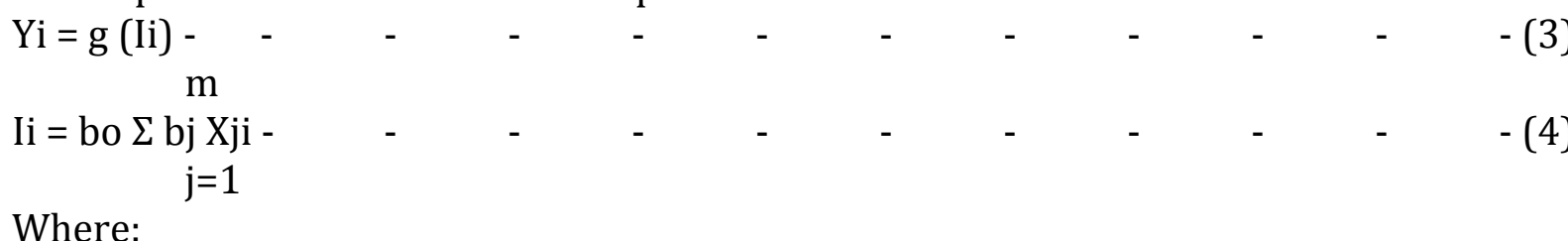

Yi is the observed response for the ith observation (i.e., the binary variable, Yi $=1$ for a food secure household and Yi = 0 for a food insecure household); Ii is an underlying and unobserved stimulus index for the ith observation for each household; if Ii * $>$ Ii the household is observed to be food secure, if $\mathrm{Ii}^{*}<$ Ii the household is observed to be food insecure; $\mathrm{g}$ is the functional relationship between the field observations (Yi); ( $\mathrm{Ii}^{*}$ ) the stimulus index determines the probability of being food secure; and (Ii) the stimulus index determines the probability of being food insecure. The empirical model used for determining factors that influenced food security status among low-income households in Maiduguri was specified as:

$\mathrm{Ii}=\mathrm{bo}+\mathrm{b} 1 \mathrm{X} 1+\mathrm{b} 2 \mathrm{X} 2+\mathrm{b} 3 \mathrm{X} 3+\mathrm{b} 4 \mathrm{X} 4+\mathrm{b} 5 \mathrm{X} 5+\mathrm{b} 6 \mathrm{X} 6+\mathrm{b} 7 \mathrm{X} 7+\mathrm{b} 8 \mathrm{X} 8+\mathrm{b} 9 \mathrm{X} 9+\mathrm{b} 10 \mathrm{X} 10+$ b11X11+b12X12+b13X13+b14X14+e - - (5)

where:

$\mathrm{Pi}=$ the probability of an ith household being food secure stands for dummy, X1 = Age of household head (AGE) in years; X2 = Income of household (HHINC) in Naira; X3 = Farm size of 
a household (FARMSZ) in hectares; X4 $=$ Household size (HHSZ); X5 = Farming experience (FARMEXP) in years; X6 = Level of education (EDUC) in years; X7 $=$ Household assets (HHAST) in Naira; X8 = Household production enterprise (FARMENT); D = 1, if yes; $\mathrm{D}=0$, otherwise; $\mathrm{X} 9$ = Household head's access to credit facilities (CREDIT) $\mathrm{D}=1$ if yes, otherwise $\mathrm{D}=$ $0 ; \mathrm{X} 10=$ Child dependency ratio $(\mathrm{CDR}) ; \mathrm{X} 11=$ Household head's access to extension agents (EXTAG) $\mathrm{D}=1$ if yes, otherwise $\mathrm{D}=0$; $\mathrm{X} 12$ = Hired Labour (HLAB) in manday; X13 = Family Labour (FLAB) in manday; and X14 = Diet Diversity (DD) in HDDS scores D $=1$, high diet diversity (6-12); $\mathrm{D}=0$, low diet diversity (0-5); bo = constant; and e = error term.

\section{RESULTS AND DISCUSSION}

The socio-economic characteristics of respondents in the urban settlements showed that respondents spent an average of nine years in formal education and had mean age of 47 years. This implies that majority of the respondents are educated and in their economic active years to support the rigors of general livelihood sustenance. The households had an average of 6 persons per households. This shows that the households' size is moderate. The mean farm size of 0.7 hectares shows that majority of the respondents are not farmers. This implies that respondents obtain most food items from the market, at the prevailing prices which may affect the level of household consumption. Household income is a key factor in determining economic access to food in the study area. Due to the cosmopolitan nature of the urban settlements, urban farming and or household gardening are not sufficient to meet the food needs. Sufficient income is required for livelihood sustenance especially food consumption. The mean monthly income for the respondents was about N69,000.00 Mean farming experience of 6 years is an indication of

Table 2: Socio-economic Characteristics of Respondents

\begin{tabular}{ll}
\hline Factors & Urban $(\mathbf{n}=\mathbf{3 6 0})$ \\
& Mean \\
\hline Education (yrs) & 9.0 \\
Age (yrs) & 47 \\
Household size & 6.2 \\
Farm size (ha) & 0.7 \\
Monthly Income (N) & $68,814.6$ \\
Farming Experience (yrs) & 6.0 \\
CDR & 0.2 \\
Cost of family Labour (N) & $8,253.9$ \\
Cost of hired Labour (N) & $97,177.82$ \\
Assets (N) & $845,364.67$ \\
\hline
\end{tabular}

Source: Field Survey, 2011.

the low level of households' involvement in crop production. Mean cost of hired labour is high as households engage in other income generating activities such as poultry, fish farming, agroprocessing, petty trading etc that require labour outside the family setup. Average value of asset amounts to N845,364.00. This implies that these assets can be liquidated in lean periods to meet households' food requirements. 
In Table 3, other socio-economic characteristics were further explained. Household heads in the study area were mostly males (96\%). This is in consonance with the religious inclinations of the respondents. Majority (74\%) of the respondents had no cooperative affiliation.

Table 3: Other Socio-economic Characteristics of Urban Households

\begin{tabular}{|c|c|c|}
\hline \multirow[t]{2}{*}{ Other Socio-economic factors } & \multicolumn{2}{|c|}{ Urban $(n=360)$} \\
\hline & Frequency & Percentage \\
\hline \multicolumn{3}{|l|}{ Gender } \\
\hline Male & 344 & 95.6 \\
\hline Female & 16 & 4.4 \\
\hline \multicolumn{3}{|l|}{ Membership of cooperatives } \\
\hline Membership & 94 & 26.1 \\
\hline Non-membership & 266 & 73.9 \\
\hline \multicolumn{3}{|l|}{ Extension contact } \\
\hline Has Contacts & 25 & 6.9 \\
\hline No Contacts & 335 & 93.1 \\
\hline \multicolumn{3}{|l|}{ Access to credit } \\
\hline Accessible & 154 & 42.8 \\
\hline Not Accessible & 206 & 57.2 \\
\hline Total & 360 & 100 \\
\hline
\end{tabular}

Source: Field Survey, 2011.

About $93 \%$ of the household heads had no contact with extension agent(s).This is further buttressed by the small farm size ( 0.7 hectares) and the low farming experience ( 6 years) as presented in Table 2. This implies that majority of urban households engage in crop production minimally.

\section{Households Income Generating Activities}

The distribution of household by types of income generating activities in the study area and their corresponding monthly income in Naira is presented in Table 4.

Table 4: Main Sources of Income and their corresponding Monthly Income

\begin{tabular}{|c|c|c|c|c|}
\hline \multirow[t]{3}{*}{ Sources } & *Percentage & \multirow{2}{*}{$\begin{array}{l}\text { Mean Household } \\
\text { Income ( } \mathbb{A})\end{array}$} & \multirow{2}{*}{$\begin{array}{l}\text { Total Income } \\
\text { Generated ( } \mathbf{A})\end{array}$} & \multirow{2}{*}{$\begin{array}{l}\text { Percentage of } \\
\text { Gross Income }\end{array}$} \\
\hline & of Total & & & \\
\hline & \multicolumn{4}{|l|}{ Respondents } \\
\hline Crop Production & 31.1 & $22,013.00$ & $2,465,456.00$ & 4.05 \\
\hline Monthly Wages & 100 & $69,433.33$ & $24,996.000$ & 41.02 \\
\hline Petty Trading & 70.3 & $51,823.33$ & $13,111,219.00$ & 21.51 \\
\hline Carpentry & 3.3 & $42,455.71$ & $509,468.52$ & 0.84 \\
\hline Barbing/Hair & 11.9 & $41,666.67$ & $1,791,666.80$ & 2.94 \\
\hline Tailoring & 8.9 & $46,145.75$ & $1,476,664.00$ & 2.42 \\
\hline Agro processing & 35.6 & $52,479.17$ & $6,717,333.80$ & 11.02 \\
\hline Fishing & 12.2 & $23,420.00$ & $1,030,480.00$ & 1.69 \\
\hline Poultry & 38.1 & $52,850.00$ & $7,240,450.00$ & 11.88 \\
\hline Livestock & 11.7 & $38,190.50$ & $1,604,001.00$ & 2.63 \\
\hline Total & & & $60,942,739$ & 100 \\
\hline
\end{tabular}

Multiple responses existed

Source: Field Survey, 2011 
Households engaged in a variety of economic activities as part of complex livelihood strategies. This can in principle have a positive effect on the food security situation of the households that engage in these activities through two main avenues: the income it generates, and the direct access to the food. These include both on-farm and off-farm income generating activities. The on-farm activities were fish farming, poultry and local livestock husbandry while off-farm activities were civil service employment, petty trading, tailoring, food processing, etc. The result showed that a total of $\mathrm{N} 60,924,739.00$ was generated per month in the urban households from both on-farm and off-farm activities. These are civil service employment, petty trading, poultry, agro-processing, crop production and barbing/hair weaving were the commonest income generating activities representing about, N24,996,000, N13,111,219.00, $\mathrm{N} 7,240,450.80, \mathrm{~N} 6,717,333.80, \mathrm{~N} 2,465,456$ and N1,791,666.80 representing $41.02 \%, 21.51 \%$, $11.88 \%, 11.02 \%, 4.05 \%$ and $2.94 \%$ of the total gross income among urban households respectively. Households engaged predominantly in off-farm activities which yielded about $71.36 \%$ of the total gross income. This depicts the economic inclination of the urban households which guaranteed households' access to food at prevailing market prices. However, about $28.64 \%$ of the total gross income was obtained from crop production and other agricultural practices.

Households' income generating activities are also forms of income diversification activities that are key factors to household food security. They provide for immediate needs of the households and also serve as buffers during lean periods. In the study area, most farms are not large enough (0.7hectares) for households to be food secure from subsistence farming alone. Households with more access to income generating activities, or access to higher paying work are expected to be more food secure than households without such benefits. All things being equal, such households generate more income which improves their economic access to food and general welfare.

Monthly wages, petty trading and poultry contributed about $41.02 \%, 21.51 \%$, and $11.88 \%$ to the gross household income in the urban area respectively. Adding such activities to a livelihood system ultimately improve food security for the households. Households' engagement in fish farming, poultry and livestock husbandry directly improves food security as some of these products are consumed. Kwaghe (2006) also reiterated that the additional income could be used to purchase farm inputs, transport, and even to expand farm lands, which tends to increase the productivity and incomes of farming households. However, the type of activity which will improve food security level for individual households will depend on household composition and resources.

\section{Measure of Caloric Intake of Respondents Mean Adult Expenditure and Calorie Intake}

The summary of mean adult expenditure on food per day and the calorie intake in the study area is presented in Table 5. The result revealed the mean adult expenditure on food and calorie intake per day among urban households. The mean adult expenditure on food per day was N676.82 and the mean calorie intake was 2,673.42 Kcal among urban households respectively. The information in Table 4 therefore shows an important element of food security, that is, the average amount of money households had spent on food and average calorie consumption in its adult equivalent. 
Table 5: Mean Adult Expenditure and Calorie Intake

\begin{tabular}{ll}
\hline Variables & Urban $(\mathbf{n}=\mathbf{3 6 0})$ \\
\hline Expenditure (N) & 676.82 \\
Calories (Kcal) & $2,673.42$ \\
\hline
\end{tabular}

Source: Field Survey and calorie estimation, 2011

The result showed a high per adult calorie intake in the urban area compared to the recommended calorie intake of $2260 \mathrm{Kcal}$. It must be noted that income levels is naturally higher among urban households, hence they had more access and expenditure on food resulting in higher calorie intake. The implication of these values is that, achieving food security in the study area depends on the aggregate availability of physical supply, access and utilization of food consistent with normal wellbeing of the households.

\section{Food Security Measure among Respondents}

The summary statistics of food security measures among urban households is presented in Table 6. Based on the recommended daily energy levels (L) of 2260 Kilocalories FAO (2009), the food security line was found to be N78.33 per day per adult equivalent for urban households. On annual basis, this is equivalent to N26,318.88 per adult for urban households. From the food security line result, $60 \%$ of the sample urban households were food secure. This implies that $40 \%$ of the sample urban households were food insecure. Food insecurity level was therefore moderate among the urban households. Furthermore, the aggregate income gap (G) of -641.47 indicates that food insecure households would need an average of N641.47 per adult to meet their monthly basic food requirements.

Differences in income levels predispose households to different consumption patterns due to their economic access to food. Crop production which was mainly practiced by very few households did not adequately meet the food needs of urban inhabitants, hence heavy reliance on food purchased from the market. This ultimately depends on its availability and the prevailing market prices. Also, very few households had home gardens which may likely reduce household cost on mainly vegetables. Naturally, cost of living tends to be higher in the urban settlements due to its cosmopolitan nature. Therefore, the tendency of a high income gap is therefore inevitable among the urban households.

Table 6: Food Security Measures among Households

\begin{tabular}{|c|c|}
\hline Households & Urban $(n=360)$ \\
\hline Constant & $4.341(49.89)^{*}$ \\
\hline $\begin{array}{l}\text { Slope coefficient } \\
\text { FAO recommended daily energy Levels (L) }\end{array}$ & $\begin{array}{l}0.0000(5.47)^{*} \\
2260 \mathrm{Kcal}\end{array}$ \\
\hline Head Count (H) & $\begin{array}{l}144 \text { (food insecure) } \\
216 \text { (food secure) } \\
-2,193.24 \text { per month }\end{array}$ \\
\hline Food security line $(Z)$ & $\$ 26,318.88$ per year \\
\hline Percentage Household & $\begin{array}{l}40 \% \text { (food insecure) } \\
60 \% \text { (food secure) }\end{array}$ \\
\hline Aggregate income gap (G) & 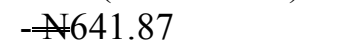 \\
\hline
\end{tabular}

t-values of estimates

Source: Estimates of OLS estimates and cost-of-calories equation, 2011 


\section{Determinants of Food Security Status among Urban Households}

The determinants of food security status in the urban area are presented in Table 7. The regression result revealed that 10 out of 14 variables included in the model were significant in explaining the variation in food security status among urban households. The significant variables at $1 \%$ level of significance were family size, education, extension agent's contact, credit, assets, income and diet diversity, while farm size, child dependency ratio and family labour were significant at 5\%. The value of R2 suggests that the model explains $86 \%$ variations in the data. The results of the significant determinants are discussed as follows:

Household Income (HHINC): A significant positive relationship existed between food security level and income level at 1\% among urban households. The possible explanation is that

Table 7: Determinants of Food Security among Urban Households

\begin{tabular}{|c|c|c|c|}
\hline Variable & Coefficient & Standard Error & t-value \\
\hline Constant & 11.34500 & 3.61200 & $3.141 * * *$ \\
\hline $\operatorname{AGE}\left(X_{1}\right)$ & 0.07453 & 0.04773 & 1.561 \\
\hline HHINC( $\left(X_{2}\right)$ & 1.21634 & 0.30753 & $3.955 * * *$ \\
\hline $\operatorname{FARMSZ}\left(\mathrm{X}_{3}\right)$ & 1.45200 & 0.59468 & $2.442 * *$ \\
\hline $\operatorname{HHSZ}\left(X_{4}\right)$ & -0.54270 & 0.20767 & $-2.613 * * *$ \\
\hline $\operatorname{FARMEXP}\left(X_{5}\right)$ & 0.16940 & 0.11275 & 1.502 \\
\hline $\operatorname{EDUC}\left(\mathbf{X}_{7}\right)$ & 0.22667 & 0.08483 & $2.672 * * *$ \\
\hline $\operatorname{ASSETS}\left(\mathrm{X}_{9}\right)$ & 0.00001 & 0.00000 & $3.187 * * *$ \\
\hline FARMENT( $\left.X_{10}\right)$ & 0.38967 & 0.42200 & 0.923 \\
\hline $\operatorname{CREDIT}\left(\mathrm{X}_{11}\right)$ & 3.53567 & 1.11467 & $3.172 * * *$ \\
\hline $\operatorname{CDR}\left(X_{12}\right)$ & -0.99877 & 0.41140 & $-2.428 * *$ \\
\hline EXTAG $\left(X_{13}\right)$ & 1.93653 & 0.61807 & $3.133 * * *$ \\
\hline $\operatorname{HLAB}\left(X_{14}\right)$ & 0.00003 & 0.00006 & 0.545 \\
\hline $\operatorname{FLAB}\left(\mathbf{X}_{15}\right)$ & 0.00040 & 0.00013 & $3.067 * * *$ \\
\hline $\begin{array}{l}\mathbf{D D}\left(\mathbf{X}_{16}\right) \\
\mathbf{R}^{2}\end{array}$ & $\begin{array}{l}0.19620 \\
88.47\end{array}$ & 0.06597 & $2.974 * * *$ \\
\hline
\end{tabular}


households having high monthly income are less likely to become food insecure than low income households as income determines purchasing power of the households at the prevailing prices. Urban households are more exposed to the consequences of rising food prices (one of which is reduction in food intake) as they are more likely to consume staple foods derived from tradable commodities (rice, wheat, etc). This further reiterates the fact that high income levels facilitate access to food in adequate quantity and quality, hence food security.

Farm Size (FARMSZ): A negative relationship existed between food security level and farm size at $5 \%$ significant level. This, however, is a departure from the a priori expectation. This indicates that farm size under cultivation in the urban area does not significantly influence the level of food availability in these households. Considerable amount of food items available in the study area are obtained from the rural areas in the State and other States in Nigeria.

Household Size (HHSZ): The coefficient of household size was found to be negative as expected and significant at 1\%. Household size either determines the availability of family labour or large household size demands large amount of production to feed its members, that is, as household size increases, the demand for food increases. Increase in family size necessitates increase in household expenditure on food and other necessities/utilities which ultimately increases food insecurity.

Level of Education (EDUC): The coefficient of the variable was significant at $1 \%$ and exhibited a positive relationship to food security as expected. In the study area, 238 (66.1\%) respondents completed secondary school education and had post-secondary education. The result agrees with economic literature in (Obamiro et al. 2004) that educational attainment at any level can significantly affect household's food security status. The result, therefore, implies that as the level of education of household heads increases, income level increases, level of awareness of food requirements increases which impacts positively on the households' nutrition decision. Food security intensity therefore increases in households with literate household heads than their illiterate counterparts and vice versa.

Household Assets (HHAST): As expected a priori, a positive relationship existed between food security level and household assets and was significant at 1\% level. Ownership of consumer durable and productive asset may likely affect households' food security status. Households can liquidate assets which makes money available to buy food during emergencies, hence food security. It is believed that the more endowed households are the more food secure they will be.

Credit Access (CREDIT): The coefficient of access to credit was significant at $1 \%$ and carries a positive sign as expected suggesting that access to credit tend to positively influence the food security level of households. Credit is an important means of investment and households who have access to credit can invest in preferred businesses (such as in poultry production and fish farming which provide easy and immediate access to animal protein), earn more income so that derived revenue increases financial capacity and purchasing power of the household to escape from risk of food insecurity. Moreover, it helps to smooth consumption when household is faced with temporary food problem. Food security status increases as households are economically empowered, all things being equal, through their investments and vice versa. 
Child Dependency Ratio (CDR): A negative relationship as expected existed between child dependency ratio and food security but was significant at 5\%. Households with high dependency ratio may lack sufficient resources to cater for their upkeep. Dependants usually do not contribute to households' financial requirements which ultimately results in over dependence on limited family resources hence food insecurity. Also, households with more young members may mean less labour available for income generating activities and other productive activities especially food production.

Contact with Extension Agent (EXTAG): The coefficient of this variable was significant at 1\% and positively relates to food security as expected. It is believed that households who have frequent contact with extension personnel and services have potential to adopt valuable extension advices and improve productivity, hence food security. Most urban households (53\%) do not engage in crop production as such only $6.9 \%$ of sample households had contact with extension agents. This outcome may likely affect the level of food production, hence food security status in the study area.

Family Labour (FLAB): As expected, the coefficient of family labour was positive and significant at 5\% level indicating that food security status of households will increase with increased availability of family labour and vice versa. Family labour is usually employed for own-food production and output may sometimes depend on labour availability. In the study area, as presented in Table 7, households engage in petty trading, agro-processing and poultry production which are sources of considerable income to support their livelihood.

Diet Diversity (DD): The coefficient of this variable was significant at $1 \%$ with a positive sign as expected. This is an indication of both physical and economic access to required food items. Food diversity in the urban area may likely depend on income level. This implies that the extent of households' food diversity intake is also an indication of their food security status.

\section{CONCLUSIONS AND RECOMMENDATIONS}

The study concluded that some socio-economic characteristics of respondents captured in the Logit model influenced their food security status. Furthermore, the study observed that food security level among the households in the urban area hinges significantly on the income levels of the household heads.

Based on the findings of this study, the following policy measures aimed at improving households' food security status in the study area were recommended.

i. Household income was identified as one of the significant determinants of food security among households in the urban area. It is important that improving wage earning capacity and exploring income diversification opportunities are crucial in enhancing food security status of households. This will involve combination of enterprises and offfarm activities that could generate more income for the households in order to be able to meet their minimum food requirement.

ii. Large household sizes and high dependency ratio were found to affect household food security in the study area. Therefore, policy measures directed towards the provision of better family planning, increased awareness and access to family planning facilities should be given adequate attention and priority by the government. In view of this, strategies for an effective community participation in the design of concepts and messages aimed at imparting knowledge about family planning to households are recommended. 


\section{References}

Ahmed, F. F. and Abba, P. O. (2014). Food Security and Coping Strategies among Low Income Earners in Maiduguri Metropolis of Borno State, Nigeria. Asian Journal of Social Sciences \& Humanities. 3(1):74-86.

Aliber, M., (2009). Exploring Statistics South Africa's national household surveys as sources of information about food security and subsistence agriculture. Pretoria: Human Sciences Research Council.

Babatunde, R.O., Omotosho, O.A., and Sholatan, O.S. (2007). Socio-economic characteristics and food security of farming households in Kwara State, North-Central Nigeria. Pakistan Journal of Nutrition, 6: 49-58.

Davies, A.E. (2009). "Food Security Initiatives in Nigeria: Prospects and Challenges”, Monograph, Department of Political Science, University of Ilorin, Nigeria.

Eze J.C. (2003). "Key Issues Affecting Nigeria's Development” Paper Presented at Workshop Private Company Chief Executives, Awka. 4 - 5 October.

Food and Agriculture Organization (FAO) (2001). State of food insecurity in the world.

Food and Agriculture Organization (FAO) (2009). Measuring Food Security Using Respondents Perception of Food Consumption Adequacy. Food and Agriculture Organization of the United Nations: Rome, Italy.

Food and Agriculture Organization. (2009). Measuring Food Security Using Respondents Perception of Food Consumption Adequacy. Food and Agriculture Organization of the United Nations: Rome, Italy.

Kaloi,E., Tayebwa, B. and Bashaasha, B. (2005): Food security status of households in Mwingi District, Kenya .Department of Agricultural Economics and Agribusiness, Makerere University, Kampala, Uganda. African Crop Science Conference Proceedings, Vol.7. pp. 867-873.

Kwaghe, P. V. (2006). Poverty Profile and its Determinants among Farming Households In Borno State. Nigeria. (Unpublished Ph.D Thesis), University of Maiduguri, Borno State. pp 22-40.

Obamiro, E.O., Doppler, W. and Kormawa, P.M. (2004). Pillars of Food Security in Nigeria.

International Institute of Tropical Agriculture, Ibadan, Nigeria.

Ojo, E.O. and Adebayo.P.F. (2012). Food Security In Nigeria: An Overview. European Journal of Sustainable Development 1(2): 199-222.

Oluyole, K.A., Oni, O.A., Omonona, B.T., and Adenegan, K.Q. (2009). Food Security among Cocoa Farming Households of Ondo State, Nigeria. ARPN Journal of Agriculture and Biological Science. 4(5):7-14.

Orewa, S.I. and Iyanbe, C.O. (2009). Determinants of Daily Food Calorie Intake among Rural and Low-Income Urban Households in Nigeria. Middle East Journal of Scientific Research 4(4): 297-306.

Greer, J., and Thorbecke, E. (1986). A methodology for measuring poverty applied to Kenya. Journal of Development Economics 24(1):59-74. 